\section{フィルター型资光光度計における 内標準法の適用}

\author{
細 川 巌, 本田サトミ, \\ 正木よし子，羽坂 忠義*
}

干渉フィルターを用いる炎光光度計は，経済的に廉価 であるうえ使用法が簡単であるため, 多くの研究室で用 いられている.しかし, フィルターの種類が現在のとこ ろ少なく，かつ内標準法が適用できないため，妨害物質 の多い試料では簡単な定量が困難である. 著者らは, こ の)種の炎光光度計に付属しているナトリウム，カリウム およびカルシウム用フィルターのほかに，リチウム，ス トロンチウムおよびセシウム用のフィルターを独自に購 入し，これらの元素の定量が可能であることを見いだし た．本報では，リチウム用フィルターを用いる内標準法 の適用と，この方法による海水およびケイ酸搷中のナト リウム拉よびカリウムの分析方法について報告卞る.

\section{1 装置と試薬}

日立製 F P F 2 型炎光光度計を用いた。発光系は酸素 $1.1 \mathrm{~kg} / \mathrm{cm}^{2}$, プロパン $0.16 \mathrm{~kg} / \mathrm{cm}^{2}$ である. この炎 光光度計付付属しているナトリウムと, カリウム用の干 涉フィルタ一打よび著者らが独自に日立製作所から購入 したリチウム用干渉フィルターの波長特性は, Table I のと扰りである。
試薬はすべて関東化学製特級試薬を用い，アルカリ金 属塩はいずれも㙁化物を用いた。

Table I 干渉フィルターの特性

\begin{tabular}{lcc}
\hline \hline 㫕 素 & $\begin{array}{c}\text { 最大透過率を示す波長 } \\
(\mathrm{m} \mu)\end{array}$ & $\begin{array}{c}\text { 最大輝度の } 1 / 2 \text { における波長幅 } \\
(\mathrm{m} \mu)\end{array}$ \\
\hline $\mathrm{Na}$ & 592 & 4 \\
$\mathrm{~K}$ & 778 & 4 \\
$\mathrm{Li}$ & 675 & 5 \\
\hline
\end{tabular}

\section{2 内標準法による分析操作}

リチウム $100 \mathrm{ppm}$ を共存する試料液を調製し，あら かじめ 30 分間予熱した炎光光度計リチウム用フィルタ 一を入机，透過率が 100\% になるようにスリットを調 節する.調整後，ての方まのスリットの状態で，フィル ターを取り替え，ナトリウムまたはカリウム用のものを 入れ，そのときの輝度を読み取る。このような操作で得 られた測定值（Table II および III）から，それぞれ の元素の検量線が得られる.

\section{3 他元素の妨害}

2 の方法で，ナトリウム抢よ゙カリウム定量すると き，カルシウム，その他マグネシウムなどが共存する際 の妨害程度を調べた。

以上の結果から，上記 2 の方法によってナトリウムお よびカリウムを定量するとき，カルシウムその他マグネ シウムなどの妨害による実験誤差は，だいたい５\%以内 であることがわかる。

Table II ナトリウムに対する妨害（輝度 \%)

\begin{tabular}{|c|c|c|c|c|c|c|c|c|c|c|c|c|c|}
\hline 妨害イオン & & \multicolumn{4}{|c|}{$\underbrace{\mathrm{K}^{+}}$} & \multicolumn{4}{|c|}{$\mathrm{Ca}^{2+}$} & \multicolumn{4}{|c|}{$\mathbf{M g}^{2+}$} \\
\hline $\mathrm{Na}^{+}$濃度 $(\mu \mathrm{g} / \mathrm{ml})$ & & 5 & 10 & 15 & 20 & 5 & 10 & 15 & 20 & 5 & 10 & 15 & 20 \\
\hline & $\begin{array}{l}0 \\
5\end{array}$ & $\begin{array}{l}15.7 \\
16.1 \\
(17.4)\end{array}$ & $\begin{array}{c}23.7 \\
23.4 \\
(25.9)\end{array}$ & $\begin{array}{l}29.2 \\
28.7\end{array}$ & $\begin{array}{c}32.4 \\
33.0 \\
(33.4)\end{array}$ & 15.7 & 23.7 & 29.2 & 32.4 & 15.7 & 23.7 & 28.8 & 32.5 \\
\hline 妨害イオン量 $(\mu \mathrm{g} / \mathrm{m} l)$ & $\begin{array}{l}10 \\
20\end{array}$ & $\begin{array}{c}(17.4) \\
16.3 \\
(19.5) \\
16.3 \\
(21.1)\end{array}$ & $\begin{array}{c}(25.9) \\
23.7 \\
(26.5) \\
23.8 \\
(28.0)\end{array}$ & $\begin{array}{l}28.9 \\
29.0\end{array}$ & $\begin{array}{c}(33.4) \\
33.0 \\
(36.0) \\
33.1\end{array}$ & $\begin{array}{c}16.2 \\
(16.9) \\
16.2 \\
(17.4)\end{array}$ & $\begin{array}{c}24.2 \\
(25.3) \\
23.9 \\
(26.0)\end{array}$ & $\begin{array}{c}29.3 \\
(30.2) \\
28.6 \\
(30.8)\end{array}$ & $\begin{array}{c}33.4 \\
(34.0) \\
31.9 \\
(34.6)\end{array}$ & $\begin{array}{c}16.2 \\
(18.8) \\
16.4 \\
(19.0)\end{array}$ & $\begin{array}{c}23.8 \\
(25.3) \\
24.0 \\
(25.5)\end{array}$ & $\begin{array}{c}29.4 \\
(29.8) \\
29.8 \\
(30.2)\end{array}$ & $\begin{array}{c}33.5 \\
(33.8) \\
33.8 \\
(34.2)\end{array}$ \\
\hline
\end{tabular}

（）は内慓隼法によらず直接に測定した值

Table III カリウムに対する妨害（輝度 \%)

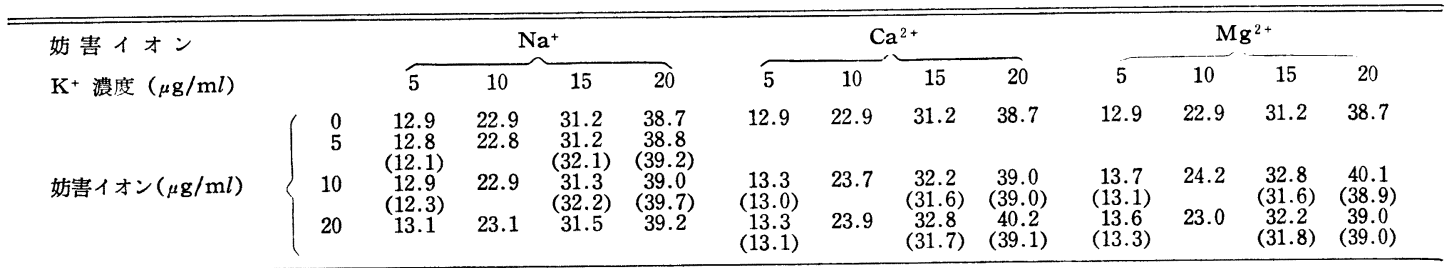

* 福岡学芸大学: 福岡市塩原町 
4 海水中のナトリウムおよびカリウムの定量

両イオンの潭度がそれぞれ $20 \mathrm{ppm}$ 以下になるよう に，をず海水空希䣋する。標準海水ではナトリウム濃度 は約 $10,000 \mathrm{ppm}$ ，カリウムでは約 $380 \mathrm{ppm}$ であるか ら，前者の場合は 500 倍，後者では 20 倍にそれぞれ うするる。.

実際操作としては，まず， $20 \mathrm{ml}$ メスフラスコに海水 $1 \mathrm{~m} l$ をとり定容にする。この希秎液の $5 \mathrm{~m} l$ 它取りだ し, リチウム標準液 (Li $200 \mathrm{ppm}) 5 \mathrm{ml}$ を加光, 上く まぜたもの空カリウム定量に用いる。また，上の肴釈液 $2 \mathrm{ml}$ 总 $50 \mathrm{ml}$ メスフラスコにとり, 定容としたのち, この液の $5 \mathrm{ml}$ を取りだし，リチウム標準液（Li 200 ppm） $5 \mathrm{~m} l$ を加光た液でナトリウムを定量する.

この操作により，定量の際には海水は 1000〜40 倍に うすめられ，カルシウムおよびマグネシウムの濃度に対 するナトリウム晾よびカリウム濃度の関係は, Table II および III の範围にはいることになる。

添加法によって, 海水中のナトリウムおよびカリウム の回収率を検討したところ，Table IV のようにナトリ ウムでは平均 100\%，カリウムでは平均 98\% であった。

Table IV 海水での回収率

\begin{tabular}{|c|c|c|}
\hline & $\begin{array}{c}\mathrm{Na}^{+}(1000 \text { 倍の希秎海水 }) \\
(\mu \mathrm{g} / \mathrm{m} l)\end{array}$ & $\begin{array}{c}\mathrm{K}^{+}(40 \text { 倍の希㗭海水) } \\
(\mu \mathrm{g} / \mathrm{m} l)\end{array}$ \\
\hline 测 定 值 & 10.2 & 9.5 \\
\hline 添 加 量 & 2.5 & 5.0 \\
\hline 回 収 量 & $2.5,2.4,2.6$ & $4.8,5.0,4.8$ \\
\hline 平均回収率 $(\%)$ & 100 & 98 \\
\hline
\end{tabular}

以上の結果から，4の方法で海水中のナトリウムおよ びカリウム空定すると，いずれも $4 \%$ 以内の誤差で測 定が可能である.
5 ケイ酸塩中のナトリウムおよび カリウムの定量

ケイ酸塩（主として岩石）試料 $0.4 \mathrm{~g}$ を精ひょうした ものを，常法によりフッ化水素酸で処理したのちフッ化 水素を除き, 希硝酸 $250 \mathrm{~m} l$ で溶かした溶液から, $5 \mathrm{~m} l$ を取りだし，標準りチウム液（Li 200ppm） $10 \mathrm{ml}$ と水 $5 \mathrm{~m} l$ を加光たものを試液とし， 2 の方法で定量する. 5 種の海底たい積物を試料として, 添加法で回収率を求 めた結果を Table V に示した。

これらの結果から， 2 の方法によりナトリウム，カリ ウムとも $3 \%$ 以内の誤差で定量できる可能性がある.

この方法で得られた測定值を，同一試料について他の 研究者による值と比較した (Table VI).

これらの結果からみて，5の方法による測定值は，よ く他の測定值と一致していることがわかる.

Table VI 分析値の比較

\begin{tabular}{|c|c|c|c|c|}
\hline \multirow{2}{*}{ 試 料 } & \multicolumn{2}{|c|}{$\begin{array}{l}\text { 玄䵧岩賈安山岩 } \\
\text { (香川首小息) }\end{array}$} & \multicolumn{2}{|c|}{$\begin{array}{l}\text { 海底たい積土 } \\
\text { (有明海㴒部) }\end{array}$} \\
\hline & $\mathrm{Na}_{2} \mathrm{O}(\%)$ & $\mathrm{K}_{2} \mathrm{O}(\%)$ & $\overparen{\mathrm{Na}_{2} \mathrm{O}(\%)}$ & $\mathrm{K}_{2} \mathrm{O}(\%)$ \\
\hline 著者らの分析值 & 3.10 & 2.25 & 2.04 & 2.16 \\
\hline 桂 敬の分析値† & 3.01 & 2.31 & & \\
\hline 市原倀子の分析值十 & & & 1.99 & 2.25 \\
\hline
\end{tabular}

$\dagger$ 福岡学芸大学地学教室山本博達から恵与された試料で, 分析值はこ れに添付されていたもの.

†十 資源科学研究所桑野幸夫から恵与された試料.

$$
6 \text { 結語 }
$$

フィルター型炎光光度計に, リチウム用フィルターを 用いて，リチウムによる内標準法が適用できることを明 らかにした。この方法により，海水中のナトリウムおよ びカリウムは, 海水試料 $1 \mathrm{~m} l$ で誤差おのおの $4 \%$ 以内 で定量できる.また，ケイ酸塩のナトリウムおよびカリ ウムも誤差 $3 \%$ 以内で定量可能である.

(昭和 39 年 4 月 27 日受理)

Table V ケイ酸塩での回収率

\begin{tabular}{|c|c|c|c|c|c|c|c|c|c|c|}
\hline & \multicolumn{5}{|c|}{$\mathrm{Na}$} & \multicolumn{5}{|c|}{$\mathrm{K}$} \\
\hline & 1 & 2 & 3 & 4 & 5 & 1 & 2 & 3 & 4 & 5 \\
\hline 测 定 值 $(\mu \mathrm{g} / \mathrm{g})$ & 302 & 434 & 404 & 130 & 280 & 80 & 104 & 88 & 170 & 260 \\
\hline 添 加 量 $(\mu \mathrm{g} / \mathrm{g})$ & 10 & 30 & 20 & 20 & 20 & 10 & 20 & 30 & 50 & 50 \\
\hline 回 収 量 $(\mu \mathrm{g} / \mathrm{g})$ & 9.9 & 31.0 & 20.5 & 19.5 & 19.3 & 9.8 & 20.3 & 29.0 & 50.5 & 48.5 \\
\hline 回 收率 $(\%)$ & 99 & 103 & 102 & 97 & 97 & 98 & 102 & 97 & 101 & 97 \\
\hline 平均回収率 $(\%)$ & & & 99.6 & & & & & 99.0 & & \\
\hline
\end{tabular}

